\title{
STRATEGI ADAPTASI EKONOMI NELAYAN BUGIS BATULAWANG, KEMUJAN, KARIMUNJAWA ${ }^{1}$
}

\author{
Dhanang Respati Puguh, Rabith Jihan Amaruli, Mahendra P. Utama \\ Departemen Sejarah Fakultas Ilmu Budaya Universitas Diponegoro \\ Jl. Prof. Soedarto, S.H. Kampus Undip Tembalang - 56025 \\ Alamat Korespondensi: dhanang_puguh@yahoo.com \\ Diterima/ Received: 20 Desember 2015; Disetujui/ Accepted: 28 Januari 2016
}

\begin{abstract}
This paper discusses about economics adaptation strategies among Bugis's fishermen in Batulawang, Kemujan, Karimunjawa. This region status has been changed since 1980 s as a Marine Nature Reserve, and later became a National Park in the 1990s, it has led to significant changes socially and economically. A zonning enforcement conducted by the Karimunjawa National Park has been affected on gaining access of economic and livelihoods, it is forced people to adapt. There are several forms of economic adaptation strategies are executed, the faithful in fishing activity by modifying fishing gear and run the new economic activities related to the potential marine tourism in the region.
\end{abstract}

Keywords: adaptation strategy, fisherman, Bugis, Karimunjawa.

\begin{abstract}
Abstrak
Tulisan ini mengkaji tentang strategi adaptasi ekonomi nelayan Bugis di Dusun Batulawang, Kemujan, Karimunjawa. Perubahan status yang terjadi di kawasan ini pada 1980-an sebagai Cagar Alam Laut, kemudian menjadi Taman Nasional pada 1990-an, telah memunculkan perubahan-perubahan penting di kawasan tersebut. Pemberlakukan zonasi oleh Balai Taman Nasional, yang telah mempengaruhi perolehan akses ekonomi dan matapencaharian, telah memaksa masyarakat untuk beradaptasi. Terdapat beberapa bentuk strategi adaptasi ekonomi yang dijalankan, yakni setia pada aktivitas penangkapan ikan dengan melakukan modifikasi alat tangkap dan menjalankan aktivitas ekonomi baru berkaitan potensi wisata bahari di kawasan tersebut.
\end{abstract}

Kata kunci: strategi adaptasi, nelayan, Bugis, Karimunjawa.

\section{PENDAHULUAN}

Sebagian besar orang Bugis hidup dari aktivitas perdagangan laut. Mereka menguasai jalur-jalur perdagangan laut sehingga mereka juga dikenal sebagai pelaut (Pelras, 2004: 45). Keterikatan pada laut sekaligus telah menjadikan mereka dikategorikan sebagai etnis maritim. Mengikuti Susilowati (2012: 117), etnis maritim merujuk pada kelompok sosial yang pada umumnya menggantungkan sepenuhnya atau sebagian terbesar kehidupan ekonominya pada pemanfaatan sumber daya laut. Meskipun demikian, kehidupan ekonomi yang berbasis pada pemanfaatan sumber daya laut tentu bukan satu-satunya kriteria untuk menyebut suatu kelompok sosial sebagai etnis maritim. Kriteria lain yang tidak kalah penting adalah pandangan dunia yang berorientasi ke laut, yang membentuk kekhasan budaya etnis maritim baik berupa sistem budaya atau adat-istiadat, sistem sosial atau pola perilaku maupun artefak atau material budaya. Dalam garis ini, perekonomian yang berbasis pada pemanfaatan sumber daya laut dapat dilihat 
sebagai pantulan dari pandangan dunia yang berorientasi ke laut.

Aktivitas perdagangan laut juga mempengaruhi terbentuknya tradisi merantau di kalangan orang Bugis. Dalam sistem budaya mereka dapat ditemukan falsafah hidup yang terkait dengan laut dan tradisi merantau yang diekspresikan antara lain melalui ungkapan. Sebagai contoh adalah palettui alemu riolo tejjokamu, bahwa orang yang hendak merantau harus mengetahui tempat yang akan dituju dan lingkungan sosial dan budaya masyarakat setempat. Contoh yang lain adalah pura babbara sompeku pura tangkisi gulikku, ulebbireng tellengnge natowalia, yang artinya 'sudah kukembangkan layar dan sudah terpasang kemudi, jika mundur lebih baik tenggelam bersama perahu'. Falsafah ini menegaskan bahwa orang Bugis yang merantau harus memiliki pendirian yang teguh dan kesiapan menghadapi segala risiko (Hamid, 2005: 115). Falsafahfalsafah hidup itu menunjukkan bahwa merantau telah menjadi bagian dari dunia orang Bugis. Sebagian dari mereka kemudian menetap di daerah perantuan. Itu sebabnya pemukimanpemukiman Bugis dapat dijumpai di berbagai daerah pesisir Indonesia. Aktivitas merantau orang Bugis ke berbagai penjuru Nusantara diperkirakan telah berlangsung sejak abad ke-15. Mereka bermigrasi atau merantau karena berbagai alasan, misalnya untuk menghindari situasi yang tidak aman akibat konflik antarkerajaan di daerah asal atau untuk memperjuangkan kehidupan yang lebih baik di daerah lain (Kesuma, 2004: 136).

Salah satu daerah tujuan para perantau Bugis adalah Kepulauan Karimunjawa. Sebuah sumber menginformasikan bahwa orang Bugis diperkirakan telah melakukan pelayaran ke kepulauan ini dalam abad ke-17 dan 18 (Suliyati, 2014). Sayangnya, sampai saat ini belum diperoleh sumber yang dapat memberi gambaran yang cukup memadai mengenai masalah itu. Ada kemungkinan pula bahwa migrasi orang Bugis ke kepulauan ini terus berlangsung dalam abad-abad sesudahnya. Beberapa studi mutakhir mengungkapkan bahwa dalam dekade 1950-an telah muncul pemukiman-pemukiman baru orang Bugis di Kepulauan Karimunjawa, sehingga dapat diduga bahwa mereka datang dalam jumlah yang cukup besar. Dalam dekade itu Sulawesi sedang mengalami kekacauan dan situasi yang tidak aman akibat pemberontakan. Kondisi itu telah mendorong orang Bugis dari berbagai daerah seperti Bone, Wajo, Makassar, Pinrang, dan Sidenreng Rappang untuk meninggalkan tanah asal mereka ke daerah yang lebih aman termasuk Kepulauan Karimunjawa. Di kepulauan ini mereka menetap dan hidup berdampingan dengan etnis-etnis migran yang lain baik dari Sulawesi, misalnya Luwu dan Mandar, maupun dari Jawa dan Madura (Jurusan Sejarah dan Program Magister Ilmu Sejarah Universitas Diponegoro, 2012; Susilowati dan Amaruli, 2013).

Orang Bugis di Kepulauan Karimunjawa tersebar di Pulau/Desa Karimunjawa, Kemujan, Parang, dan Genting. Komunitas Bugis yang terbesar terdapat di Desa Kemujan. Di desa ini mereka dapat ditemukan di setiap dusun, tetapi yang dominan adalah di Dusun Batulawang. Sampai dengan Juni 2012, orang Bugis di dusun ini sekitar 150 keluarga. Identitas Bugis yang tampak jelas di Batulawang bukan hanya didemonstrasikan oleh komposisi penduduknya yang mayoritas beretnis Bugis, tetapi juga oleh sejumlah unsur budaya yang khas Bugis seperti rumah panggung, 'uang naik' dalam adat perkawinan, ritus peralihan, dan bahasa. Orangorang dari etnis lain yang menikah dengan orang Bugis dari Batulawang dan kemudian tinggal di dusun itu juga menggunakan bahasa Bugis dalam hubungan sosial sehari-hari. Simbol-simbol identitas Bugis yang menonjol di Batulawang membuat dusun itu dijuluki 'Kampung Bugis' biarpun dalam kenyataan di sana ada pula beberapa keluarga Mandar, Jawa, dan Madura (Amaruli, 2013). Simbol-simbol identitas orang Bugis di desa-desa lain tidak mudah dilihat. Selain jumlah anggotanya tidak sebanyak orang Bugis di Batulawang, orang Bugis di desa-desa lain itu telah hidup menyatu dengan etnis lain dalam lingkungan pemukiman yang sama. Di 
Desa Parang, misalnya, orang Bugis menyatu dalam pemukiman yang didominasi oleh etnis Jawa. Hubungan sosial yang intensif membuat mereka terserap ke dalam cara hidup orang Jawa sehingga bentuk rumah, tradisi, kebiasaan, dan bahasa mereka tidak lagi memperlihatkan ciriciri yang khas Bugis (Suliyati, 2014).

Perbedaan di antara komunitas Bugis itu menjadi pertimbangan untuk mengarahkan rencana penelitian ini pada komunitas Bugis di Dusun Batulawang. Namun demikian, berbeda dari studi-studi sebelumnya, antara lain dari Amaruli (2013), Susilowati dan Amaruli (2013), dan Suliyati (2014) yang menekankan pada etnisitas dan harmoni serta kohesivitas sosial, penelitian ini akan difokuskan pada kehidupan ekonomi komunitas Bugis.

Walaupun secara umum telah mendapat pengakuan sebagai etnis maritim, Pelras (2004: 4) menegaskan, bahwa orang Bugis semula hidup dari aktivitas pertanian dan perkebunan. Dalam beberapa studi yang lebih awal tentang orang Bugis di Desa Kemujan juga ditemukan riwayat kemunculan pusat-pusat pemukiman atau dusun-dusun di desa itu pada 1950-an. Pusat-pusat pemukiman itu semula berupa hutan. Para perantau Bugis yang datang dalam dekade itu membuka lahan dengan membabad hutan. Selain untuk membangun rumah tinggal, lahan yang mereka buka digunakan untuk menanam padi dan pohon buah-buahan seperti kelapa, mangga, sukun, jambu mete, dan rambutan. Kopra merupakan komoditas perkebunan yang penting dalam perekonomian rakyat di kepulauan itu setidaknya sampai 1970an. Dalam dekade ini pula, pemanfaatan sumber daya laut khususnya perikanan laut menjadi semakin penting dalam kehidupan ekonomi di kepulauan itu. Perubahan itu diikuti dengan terjadinya pergeseran matapencaharian dari kegiatan pertanian dan perkebunan ke kegiatan penangkapan ikan di laut. Menangkap ikan di laut menjadi kegiatan ekonomi yang pokok bagi orang Bugis di Batulawang. Mereka melakukan penangkapan ikan dengan peralatan tradisional di perairan pantai (Susilowati dan Amaruli, 2013).
Pemerintah sejak 1980-an menunjukkan perhatian yang serius untuk meningkatkan produk-tivitas sektor perikanan laut melalui revolusi biru yang diwujudkan dalam bentuk pemberian bantuan modal dan modernisasi peralatan tangkap. Kebijakan ini mencerminkan pengakuan terhadap kontribusi sektor perikanan laut yang penting dalam perekonomian nasional. Revolusi biru sempat membawa nelayan pada masa kejayaan dan bahkan mampu menarik minat para pengusaha Tionghoa untuk menginvestasikan modalnya dalam sektor perikanan laut (Semedi, 2003; Widodo, 2005). Namun demikian, keberhasilan revolusi biru telah mengundang kritik karena keberhasilan itu dianggap hanya didasarkan pada ukuran kuantitatif. Program-program yang diturunkan dari kebijakan itu dalam kenyataan tidak dapat diakses secara merata oleh semua nelayan. Oleh karena itu, revolusi biru dinilai lebih menguntungkan pengusaha dan lapisan nelayan yang bermodal besar dan menguasai alat produksi. Di pihak lain nelayan tradisional dan nelayan buruh harus berjuang demi kelangsungan hidup mereka yang hampir tidak pernah lepas dari belitan kemiskinan (Mubyarto, Sutrisno, dan Dove, 1984).

Sejak akhir 1980-an juga terjadi perubahan penting sejalan dengan penetapan Kepulauan Karimunjawa sebagai Cagar Alam Laut, yang sejak 1990-an ditingkatkan menjadi Balai Taman Nasional (BTN). Bersandar pada kebijakan itu, maka kawasan daratan dan perairan Kepulauan Karimunjawa dibagi menjadi beberapa zona yang secara garis besar dapat dibedakan menjadi zona konservasi dan zona pemanfaatan. Di dalam zona konservasi tidak diperkenankan adanya aktivitas yang dapat mengganggu keutuhan dan keseimbangan ekosistem darat maupun laut. Sementara itu, bagian-bagian kawasan yang tercakup dalam zona pemanfaatan sejak beberapa tahun terakhir ini mulai dikembangkan untuk pariwisata (BTN, 2009; BTN, 2012; serta Susilowati dan Amaruli, 2013).

Penetapan Kepulauan Karimunjawa sebagai Balai Taman Nasional tentu memengaruhi 
kehidupan ekonomi penduduk setempat terutama bagi mereka yang selama ini menggantungkan kelangsungan hidupnya dari pemanfaatan sumber daya alam. Bagi nelayan, penetapan sebagian kawasan perairan laut sebagai zona konservasi berdampak pada terbatasnya area penangkapan ikan. Pada saat yang bersamaan mereka kalah bersaing dengan nelayan dari daerah-daerah lain yang memasuki wilayah perairan laut Karimunjawa dengan peralatan yang lebih moderen. Di sisi lain, pengembangan zona pemanfaatan untuk kepentingan pariwisata telah menciptakan peluangpeluang ekonomi baru yang sekaligus dapat mengurangi ketergantungan penduduk setempat terhadap sumber daya alam.

Pilihan atas suatu matapencaharian merupakan hasil adaptasi manusia terhadap lingkungan, baik lingkungan alamiah maupun sosial, untuk mendapatkan keuntungan guna memenuhi kebutuhan hidup. Manusia memiliki kecenderungan untuk memaksimalisasi keuntungan dengan berbagai cara. Kendati demikian, usaha untuk memaksimalisasi keuntungan itu tidak hanya didasarkan pada pertimbangan rasional yang mengacu pada perhitungan untung-rugi dalam pengertian ekonomi yang konvensional. Berdasar pada kajian tentang kehidupan ekonomi masyarakatmasyarakat skala kecil di Afrika, Asia, dan Amerika Latin, Sutti Ortiz menemukan bahwa keputusan-keputusan ekonomi ternyata dipengaruhi oleh aspek sosiokultural seperti persepsi aktor, relasi sosial, kewajiban-kewajiban sosial, dan identitas serta keberlangsungan hidup. Oleh karena itu, Ortiz menggambarkan bahwa manusia hidup dalam dunia yaitu dunia pasar dan dunia sosial. Kedua dunia itu dapat dibedakan, tetapi tidak dapat direduksi sebagai dua realitas yang sama sekali terpisah (Ortiz, 2005: 59 dan 74).

Berdasar pada pemahaman itu, kajian mengenai strategi adaptasi ekonomi nelayan Bugis di Batulawang akan diarahkan untuk menjawab pertanyaan-pertanyaan berikut. Pertama, faktor-faktor apa yang mendorong terjadinya perubahan matapencaharian dari pertanian dan perkebunan ke kegiatan kenelayanan? Kedua, bagaimana strategi adaptasi orang Bugis untuk mempertahankan kelangsungan hidup mereka sebagai respon terhadap perubahan-perubahan akibat modernisasi peralatan tangkap dan penetapan Kepuluauan Karimunjawa sebagai Balai Taman Nasional? Ketiga, aspek-aspek sosiokultural apa yang sangat mempengaruhi keputusankeputusan ekonomis orang Bugis di Batulawang?

Lokasi penelitian ini adalah Dusun Batulawang, Desa Kemujan, Kecamatan Karimunjawa. Penataan wilayah administrasi pemerintahan sejak 1980-an dan penetapan kawasan Karimunjawa sebagai cagar alam pada 1986, lalu menjadi taman nasional pada 1999, dan akhirnya menjadi kawasan pelestarian alam perairan pada 2001 hingga 2012 telah membawa perubahan penting bagi nelayan Bugis di Batulawang. Penelitian ini bertujuan untuk mengungkapkan strategi ekonomi nelayan Bugis Batulawang di tengah-tengah perubahan politik, ekonomi maupun lingkungan tersebut. Dalam situasi itu, fenomena-fenomena lokal perlu dipahami dalam relasinya dengan fenomenafenomena di tingkat supralokal (Kuntowijoyo, 2003: 185). Lebih lanjut seperti dikatakan oleh G.J. Renier, dinamika pada aras lokal dapat dipahami secara relatif baik justru ketika ditempatkan dalam konteks yang lebih luas yaitu dengan menggunakan referensi umum atau menghubungkannya dengan isu-isu penting di tingkat supralokal dalam suatu periode (G.J. Renier, 1997: 74).

Pengumpulan data dalam penelitian ini dilakukan melalui studi pustaka dan kerja lapangan (field work). Studi pustaka dilakukan dengan menelaah bahan-bahan pustaka baik berupa buku, artikel jurnal, hasil penelitian yang belum dipublikasikan, artikel media massa maupun dokumen pemerintah. Sementara itu kerja lapangan ditekankan pada wawancara sejarah lisan dengan para informan. Karena penelitian ini dilakukan dalam setting upaya strategi ekonomi nelayan, maka pemilihan informan akan dilakukan dengan memperhati- 
kan keterwakilan kelompok-kelompok pekerjaan dan tingkat ekonomi.

Analisis data dilakukan dengan menggunakan metode analisis kualitatif. Mengikuti Miles dan Huberman, analisis kualitatif secara prinsip mencakup tiga kegiatan yaitu reduksi data, penyajian data, dan penarikan simpulan. Reduksi data dilakukan dengan menyeleksi dan mengorganisasikan data dengan berpatokan pada isu-isu utama dan kerangka konseptual dalam penelitian ini. Penyajian data dilakukan secara naratif dengan menyusun data dan informasi yang memunginkan penarikan simpulan dan verifikasi. Verifikasi dilakukan dengan memeriksa ulang secara seksama hasil wawancara dan studi pustaka, mengatur suatu temuan di antara seperangkat data yang lain, dan membandingkan temuan dengan hasil penelitian sejenis. Proses itu sekaligus bertujuan untuk menguji kebenaran, kekokohan, dan kecocokan data (Miles dan Huberman, 1992: 16-19). Pengorganisasian data juga dilakukan dengan memperhatikan cara penataan fakta-fakta ke dalam susunan tertentu berdasarkan prinsip kronologi dan hubungan sebab-akibat (Louis Gottschalk, 2008).

\section{STRATEGI ADAPTASI EKONOMI NELAYAN BUGIS BATULAWANG}

Kusnadi (2000: 20) mendefinisikan strategi adaptasi sebagai pilihan tindakan yang bersifat rasional dan efektif sesuai dengan konteks lingkungan sosial, politik, ekonomi, dan ekologi. Dalam konteks itu, strategi adaptasi biasa dipilih oleh para penduduk miskin untuk mempertahankan eksistensi mereka. Pilihan tindakan yang bersifat kontekstual tersebut dimaksudkan untuk meng alokasikan sumber daya yang tersedia di lingkungannya guna mengatasi tekanan-tekanan sosial dan ekonomi.

Mengikuti John W. Bennett (1969), ada tiga konsep yang perlu diperhatikan dalam persoalan adaptasi, yaitu adaptive behavior (perilaku adaptif), adaptive strategies (strategistrategi adaptif), dan adaptive processes (prosesproses adaptif). Perilaku adaptif merupakan coping mechanisms atau cara-cara manusia dalam mengatur sumber daya untuk memperoleh sesuatu yang diinginkan atau untuk menyelesaikan masalah-masalah yang mereka hadapi. Strategi adaptif merupakan pola-pola yang dibentuk sebagai penyesuaian penggunaan sumber daya dan untuk menyelesaikan masalahmasalah yang mereka hadapi. Sementara itu, proses adaptasi merupakan perubahan-perubahan yang berlangsung dalam waktu yang relatif panjang (Bennett, 1969: 11). Dalam padangan Bennett, suatu perilaku dikatakan adaptif jika berhasil mencapai tujuan yang diinginkan, atau dengan kata lain hasilnya telah dapat dilihat. Dalam kenyataan, tidak setiap hasil yang diinginkan segera dapat diketahui oleh pelaku, apalagi oleh peneliti. Ini akan mendatangkan kesulitan bagi peneliti untuk berbagai perilaku sehari-hari kecuali setelah kita mengetahui adaptif tidaknya perilaku-perilaku itu. Oleh karena itu, Ahimsa-Putra (2003: 12) mengusulkan untuk memperbaiki atau memo-difikasi konsep 'adaptif dengan 'adaptasi'. Dengan konsep 'adaptasi', setiap perilaku dapat dipandang sebagai upaya untuk beradaptasi dengan lingkungan agar tujuan yang diinginkan dapat dicapai atau masalah yang dihadapi dapat diselesaikan. Konsep turunan yang kemudian diperoleh adalah perilaku adaptasi, strategi adaptasi, dan proses adaptasi. Perilaku adaptasi adalah perilaku yang ditujukan untuk memperoleh sesuatu yang diinginkan atau untuk mengatasi masalah-masalah yang dihadapi. Strategi adaptasi menunjuk pada rencana, pedoman atau petunjuk mengenai apa yang akan dilakukan atau bisa pula berarti perilaku atau tindakan-tindakan yang telah diwujudkan. Strategi adaptasi merupakan pola-pola berbagai usaha yang direncanakan oleh manusia untuk dapat memenuhi syarat minimal yang dibutuhkan dan untuk memecahkan masalahmasalah yang mereka hadapi. Pola-pola adaptasi di sini menunjuk pada pola-pola perilaku atau tindakan (Ahimsa-Putra, 2003: 12).

Sementara itu menurut Corner, seperti dikutip oleh Kusnadi (2000: 7-8), beberapa pola strategi adaptasi yang dikembangkan untuk 
menjaga kelangsungan hidup dapat berupa, 1) melakukan beraneka ragam pekerjaan untuk memperoleh penghasilan, 2) jika kegiatankegiatan tersebut masih kurang memadai, penduduk miskin akan berpaling kepada sistem penunjang yang ada di lingkungannya, 3) bekerja lebih banyak meskipun lebih sedikit masukan, 4) memilih alternatif lain jika ketiga alternatif di atas sulit dilakukan dan kemungkinan untuk bertahan hidup. Keempat pola tersebut berputar di sekitar akses sumber daya dan pekerjaan. Dalam perebutan sumber daya ini, kelompokkelompok miskin tidak hanya bersaing dengan pihak yang kaya dan kuat, tetapi juga di antara mereka sendiri.

Berangkat dari konsepsi di atas, terdapat tiga hal pokok yang menjadi strategi pilihan nelayan Batulawang, yakni pertama, setia terhadap aktivitas penangkapan ikan dengan melakukan modifikasi alat tangkap. Kedua, mendayagunakan sumber daya yang ada di lingkungan mereka, seperti berkebun dan beternak. Kemunculan peluang-peluang ekonomi baru berkaitan dengan pariwisata juga masuk dalam kategori ini. Ketiga, memilih alternatif lain untuk bertahan hidup, seperti merantau ke luar daerah dan mengikuti kerabat untuk berdagang.

\section{Setia Pada Aktivitas Penangkapan Ikan: Modifikasi Alat Tangkap}

Dalam konteks kehidupan nelayan Bugis Batulawang, beberapa bentuk adaptasi muncul berkaitan dengan disebabkan oleh perubahan fishing ground. Pembatasan zona-zona telah mempersempit ruang gerak nelayan. Sejak penetapan zonasi diberlakukan, nelayan tidak diperkenankan masuk ke wilayah perairan tertentu. Tindakan-tindakan sosialisasi zonasi, yang disebut oleh BTN sebagai konsultasi publik, baru mulai bergulir pasca-reformasi, tepatnya pada 2010 .

Akibat dari perubahan fishing ground yang paling terasa adalah keterbatasan akses para nelayan Batulawang di perairan Karimunjawa pada umumnya dan perairan Kemujan pada khususnya. Akibat lebih lanjut adalah para nelayan seolah-olah 'dipaksa' untuk mencari ikan di luar perairan Karimujawa. Kondisi tersebut pada gilirannya, memunculkan bentuk-bentuk adaptasi yang berbeda. Bagi nelayan yang memiliki cukup modal, kapal besar dengan kapasitas mesin ganda, dapat melakukan aktivitas penangkapan di luar wilayah Karimunjawa, seperti Kalimantan dan Belitung. Jamaluddin dan Kasek misalnya, dapat menjadi contoh nelayan jenis ini. Keduanya adalah sedikit dari nelayan Batulawang yang memiliki sumber daya cukup untuk melakukan penangkapan ikan di luar Batulawang dengan melibatkan saudara dan tetangga yang juga berasal dari Batulawang. Nelayan jenis ini memang membutuhkan modal yang besar, mengingat aktivitas penangkapan ikan membutuhkan waktu yang cukup lama, yakni tiga sampai lima bulan.

Selain nelayan dengan kapal besar, nelayan dengan kapal sedang juga melakukan aktivitas penangkapan ikan di luar perairan Karimunjawa sekitar 100 sampai dengan 200 mil laut. Komoditas ikan yang primadona adalah lobster, tengiri, tongkol, dan cumi-cumi. Untuk mendukung daya jelajah, kapal-kapal nelayan Batulawang telah dilengkapi dengan mesin ganda, fish finder, dan Global Positioning System (GPS). Hasil tangkapan ikan biasanya dijual di Jepara, Belitung, dan Kalimantan. Akan tetapi, tidak jarang pula nelayan dengan kapal sedang melakukan aktivitas penangkapan ikan di perairan sekitar Karimunjawa. Hal ini biasanya dilakukan oleh nelayan-nelayan dengan modal yang tidak terlalu besar. Nelayan yang tidak memiliki modal cukup, melakukan aktivitas penangkapan ikan di perairan-perairan pantai Kemujan dan Karimun-jawa. aktivitas ini dilakukan untuk sekedar memenuhi kebutuhan sehari-hari. Tidak adanya Tempat Pelelangan Ikan (TPI) yang cukup representatif di Kemujan semakin memperkuat pendapat bahwa ikan di Kemujan justru dipenuhi oleh nelayan-nelayan kecil.

Seperti halnya nelayan di tempat lain, aktivitas nelayan Batulawang sangat bergantung 
pada musim. Musim tangkap ikan pada masyarakat nelayan di Batulawang dapat dibagi dua periode, yakni pertama, musim paceklik (MaretAgustus) angin timur, dan kedua, musim teduh (September-Februari) angin barat.

Musim paceklik berlangsung sekitar Juni sampai dengan Agustus. Musim ini dikenal juga dengan sebutan musim angin timur. Pada musim ini biasanya para nelayan jarang melakukan aktvitas melaut. Pada musim ini ikan sulit didapat, bahkan kadang-kadang mereka tidak mendapatkan hasil sama sekali. Pada musim ini mereka lebih sering melakukan aktivitas di rumah. Untuk memenuhi kebutuhan rumah tangga, para nelayan Batulawang menjalankan aktivitas mancing dan berkebun. Sebagian dari mereka ada pula yang merantau ke Pulau Kalimantan dan Pulau Bangka Belitung. Di sana mereka menjalankan bisnis kayu dan perkebunan sawit (Wawancara dengan Jamaluddin dan Andi, 13 Juni 2014).

Modifikasi alat tangkap muncul sebagai upaya nelayan Batulawang untuk menyesuaikan dengan perubahan-perubahan lingkungan di sekitar mereka, utamanya yang berhubungan dengan penetapan zonasi. Di zona-zona inti dan koservasi yang dilindungi, nelayan tidak diperkenankan untuk mempergunakan alat-alat tangkap yang membahayakan biota dan ekosistem daerah zonasi. Beberapa modifikasi tersebut tampak pada modifikasi alat pancing dan jaring sebagai berikut.

Mereka yang setia pada aktivitas mancing, biasa menangkap cumi di sekitar perairan Kemujan, seperti perairan Pulau Sintok dan Tengah. Ikan yang menjadi primadona pada musim timur adalah cumi-cumi. Alat pancing yang digunakan adalah alat pancing cumi seperti ditunjukkan pada gambar 1 .

Cara penggunaan pancing cumi adalah dengan cara ditarik-tarik (digerak-gerakkan). Hal ini dilakukan karena pancing cumi tidak diberi umpan. Bentuk pancing dibuat sedemikian rupa mirip dengan ikan yang merupakan makanan cumi-cumi. Di bagian bawah pancing cumi terdapat beberapa jarum kecil yang berbentuk tumpang, yakni di atas ada beberapa jarum, di bawah pun juga ada beberapa jarum

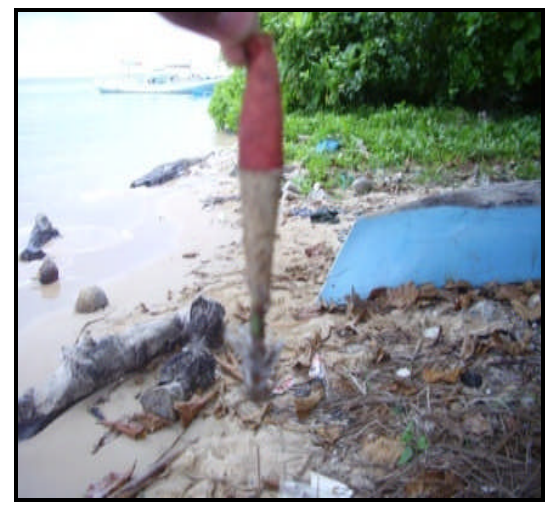

Gambar 1. Pancing cumi-cumi (Sumber: Dokumentasi Peneliti)

Selain pancing cumi, nelayan Batulawang juga menggunakan alat pancing tradisional. Memancing dilakukan para nelayan untuk mengisi waktu senggang dan sekedar memenuhi kebutuhan sehari-hari pada musim paceklik. Alat pancing pada umumnya menggunakan bambu (yang didesain sedemikian rupa) yang diberi benang pancing (nilon). Namun berbeda dengan daerah lain, banyak juga para nelayan di Batulawang yang hanya menggunakan benang saja. Selain itu, apa yang unik dari alat pancing pada nelayan Batulawang adalah penggunaan sutera sebagai pengganti umpan. Sutera dibuat sedemikian rupa mirip dengan bentuk ikan. Cara penggunaannya pun sederhana, yakni dengan cara ditarik-tarik (digerak-gerakan) agar umpan terkesan hidup (Wawancara dengan Watabe', 12 Juni 2014) seperti pada gambar 2.

Gambar 2. Alat pancing/ Umpan berbahan sutera yang dibentuk menyerupai ikan (Sumber: Dokumentasi Peneliti) 
Selain pancing, nelayan Batulawang juga mempergunakan bubu. Bubu merupakan alat sederhana yang terbuat dari bambu dan dibentuk menyerupai kandang ayam. Bubu biasa digunakan untuk menangkap kerapu. Kerapu, khususnya jenis tiger (macan), merupakan komoditas ikan yang bernilai tinggi di Karimujawa. Harga untuk $1 \mathrm{~kg}$ kerapu tiger mencapai Rp 300.000. Selain kerapu tiger, kerapu napoleon dan kerapu merah juga kerap menjadi sasaran bubu nelayan Batulawang. Cara penggunaan bubu adalah dengan dimasukkan ke dalam laut dengan diberi tanda di bagian permukaan air (ban atau plastik) sebagai penanda. Kurang lebih satu minggu kemudian bubu baru diangkat ke permukaan.

Selain bubu, kemunculan kerambakeramba di sekitar perairan Batulawang menjadi fenomena baru yang ditemukan. Kerambakeramba tersebut dibangun sebagai sarana budi daya kerapu. Keramba ini dimiliki dan diusahakan oleh beberapa nelayan Batulawang mengingat harga ikan jenis kerapu yang cukup menjanjikan. Sulaiman, salah satu pemilik keramba, menuturkan bahwa usaha budidaya kerapu cukup menjanjikan terutama ketika masa paceklik tiba (Wawancara dengan Sulaiman, 12 Juni 2014).

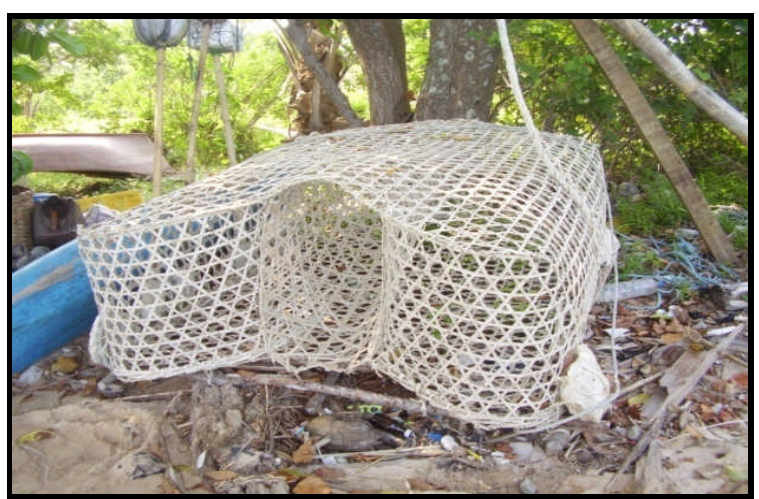

Gambar 3. Bubu yang digunakan oleh nelayan Batulawang. Bagian tengah adalah jalan masuk ikan. $B u b u$ didesain sedemikian rupa agar ikan tidak bisa keluar setelah terkena perangkap (Sumber: Dokumentasi Peneliti)

Selain nelayan, pembuat perahu juga menjadi pilihan matapencaharian nelayan Batulawang. Hal ini karena keterampilan pembuatan perahu tidak dimiliki oleh banyak orang. Sulaiman, salah satu anak dari Lato' Tawape', adalah satu-satunya nelayan pembuat perahu di Batulawang. Ia mewarisi keterampilan pembuatan perahu dari ayahnya, melalui kakaknya Adnan. Setelah Adnan memutuskan untuk berhenti membuat perahu, usaha ini dilanjutkan oleh Sulaiman di bawah bimbingan langsung ayahnya, Lato' Tawape'. Sebelumnya, Sulaiman mengikuti kakak iparnya, Jamaluddin, merantau ke Belitung (Wawancara dengan Sulaiman, 12 Juni 2014).

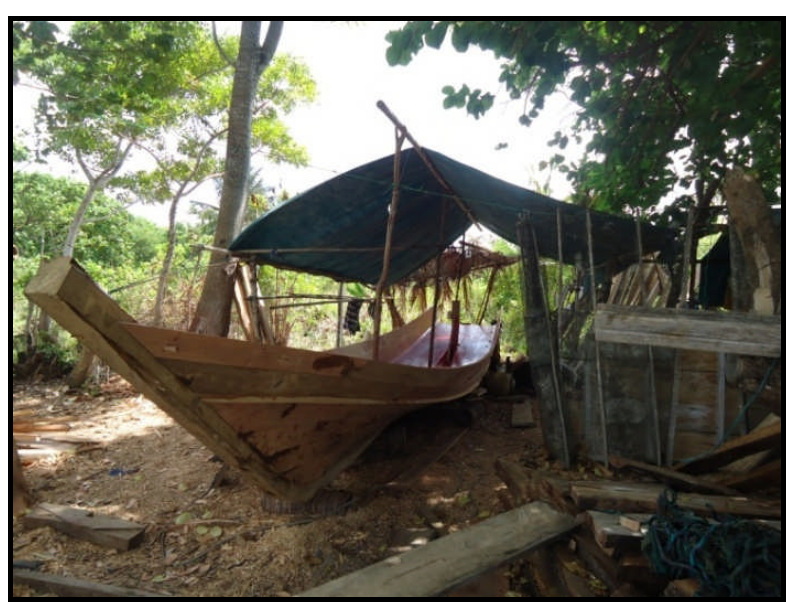

Gambar 4. Usaha pembuatan perahu milik Sulaiman di Pantai Timur Batulawang

(Sumber: Dokumentasi Peneliti)

Selain menjalankan usaha yang berhubungan dengan laut, sebagai upaya bertahan hidup nelayan Batulawang juga berternak sapi dan berkebun. Selain itu, budi daya rumput laut tampak menjadi alternatif usaha yang menjanjikan. Sepanjang musim timur, deretan rumput laut tampak mengisi beberapa bagian bibir pantai bagian barat Batulawang. Ada nelayan yang menjalankan budi daya rumput laut secara perseorangan, ada yang berperan sebagai buruh usaha ini. Hasil panen rumput laut tersebut didistribusikan ke Karimunjawa dan Jepara (Wawancara dengan Abdul Rozaq/Pak Donceng, 11 Juni 2014).

Setelah musim paceklik, nelayan Batulawang sedikit bernafas lega ketika musim teduh tiba. Musim teduh berlangung dari sekitar September sampai dengan Februari. Musim ini dikenal juga dengan sebutan musim angin barat. Nelayan Batulawang menyebut musim teduh 
sebagai musim yang baik karena pada musim ini banyak sekali ikan. Musim teduh merupakan rezeki yang melimpah bagi para nelayan Batulawang. Biasanya pada musim ini para perantau yang berada di Kalimantan dan Belitung kembali ke Batulawang. Mereka pada musim ini melakukan teknik yang berbeda, yakni dengan menggunakan mbele, njaring, mancing, dan bubu.

Mbele adalah sejenis alat seperti jaring. Akan tetapi bedanya, mbele terdiri atas jaring utama yang dilapisi jaring yang lebih kuat. Mbele terdiri atas tiga tingkatan, yakni mbele kecil untuk ikan kecil, mbele sedang untuk ikan sedang, dan mbele besar untuk ikan besar (Wawancara dengan Watabe', 12 Juni 2014; wawancara dengan Jamaluddin, 13 Juni 2014). Cara kerja alat ini unik. Ketika ikan kecil sudah masuk dalam perangkap, maka ikan yang lebih besar akan lari tetapi ikan hanya akan berlari sampai ke ujung jaring yang lebih besar, begitu seterusnya. Ukuran ujung jaring sama dengan ukuran ikan. Jadi bentuk alat tersebut menyesuaikan ikan yang didapat. Pernah suatu kali ada seorang nelayan Batulawang yang mendapatkan buaya ketika memasang jaring di pantai sebelah timur Batulawang. Bentuk dan cara kerja mbele yang rumit menyebabkan tidak semua nelayan bisa membuatnya seperti pada gambar 5 .

Selain mbele alat tangkap yang biasa digunakan oleh para nelayan Batulawang yaitu jaring. Jaring disebarkan di laut pada pada sore hari dan diambil pada keesokan paginya. Dengan menggunakan jaring, para nelayan dapat menangkap ikan lebih banyak. Pada umumnya semua nelayan memiliki cara yang sama dalam hal jaring.

Selain alat tangkap, hal yang perlu mendapat perhatian adalah bentuk dan jenisjenis kapal yang digunakan oleh nelayan Batulawang. Pada awalnya sekitar tahun 1990 para nelayan Bugis Batulawang masih mengunakan perahu layar tanpa mesin. Perahu layar sepenuhnya menggantungkan pada angin. Alat tangkap yang digunakan pun masih berupa kail atau pancing untuk menangkap ikan (Wawancara dengan Tayib, 11 Juni 2014).
Perahu ini digunakan khusus untuk pelayaran pantai di sekiar desa. Namun sejalan dengan perkembangan zaman lambat laun terjadi perubahan pada pola penangkapan ikan mulai dari jenis perahu sampai dengan peralatan yang digunakan.

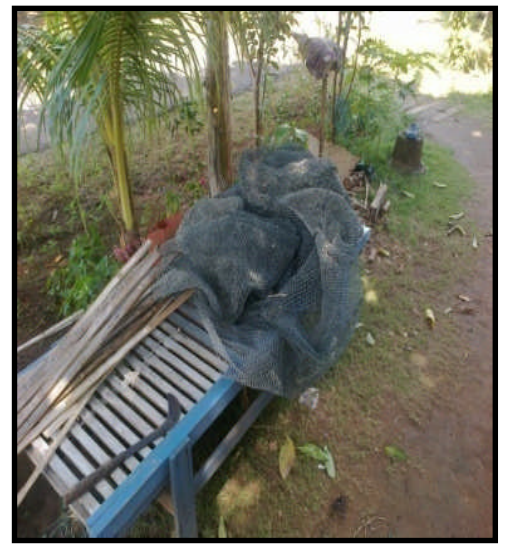

Gambar 5. Mbele yang sedang diperbaiki oleh Lato'

Tawape'. Bentuk dan cara kerja yang rumit menyebabkan tidak semua orang di Batulawang dapat membuatnya

(Sumber: Dokumentasi Peneliti)

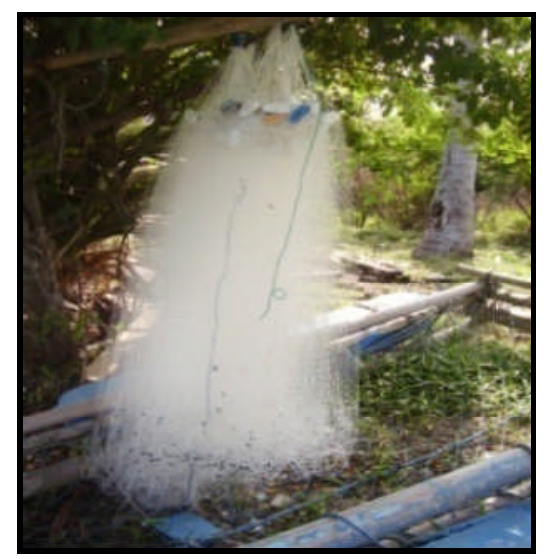

Gambar 6. Jaring yang biasa digunakan oleh Nelayan Batulawang

(Sumber: Dokumentasi Peneliti)

Revolusi biru dalam bentuk motorisasi yang dijalankan di Jawa pada 1980-an tampaknya tidak sampai ke Karimunjawa. Sampai dengan awal 2000-an, di Batulawang masih ditemukan perahu-perahu layar tanpa mesin yang digunakan untuk mencari ikan. Para nelayan yang tidak mempunyai perahu sendiri, biasanya menyewa (menjalankan) perahu orang lain dengan harus menyerahkan separuh hasil tangkapannya. 
Hal ini sebagai imbalan sewa perahu atau uang cicilan jika sang nelayan memiliki hutang kepada sang pemilik perahu.

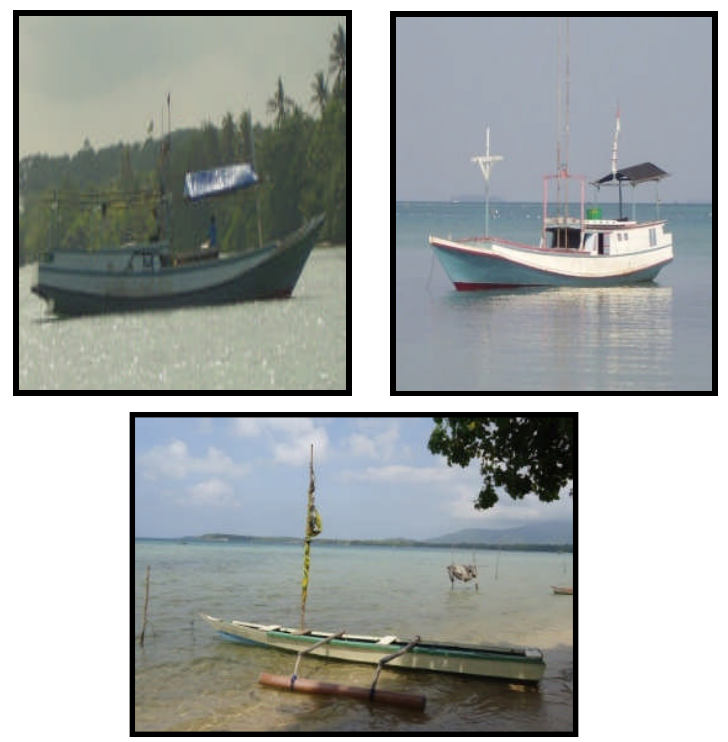

Gambar 7. Kapal jenis besar (kiri), kapal jenis sedang (kanan), kapal kecil/ nelayan pantai (bawah)

(Sumber: Dokumentasi Peneliti)

Sesuai bentuk dan peruntukkannya, terdapat dua jenis kapal, yakni besar dan sedang. Jenis kapal yang berukuran besar dapat memuat lima sampai 10 awak kapal. Kapal jenis ini memiliki muatan yang cukup besar dengan kapasitas lambung yang besar. Para nelayan yang menggunakan kapal jenis besar adalah mereka yang berorientasi pada aktivitas menjaring. Hal ini karena jenis kapal dengan lambung yang lebih besar ini dapat dapat memuat lebih banyak ikan. Jenis kapal sedang merupakan kapal yang memiliki ukaran yang sedang dengan muatan tiga awak kapal. Kapal ini berorientasi pada nelayan yang hanya berorientasi pada teknik bubu, dan mancing.

Berdasar penelusuran di lapangan, sebagai akibat dari kondisi ekonomi adalah perubahan dalam kehidupan ritual nelayan. Nelayan Batulawang dahulu menjalankan ritual yang dianggap sakral. Ritual tersebut dipercaya oleh masyarakat nelayan Batulawang sebagai ritual memberi sesembahan terhadap pemilik lautan agar dimudahkan segala rezeki. Sesembahan itu dikenal dengan istilah sedekah laut. Akan tetapi, kegiatan tersebut sudah menghilang di Batulawang. Menurut para tokoh masyarakat, penyelenggaraan sedekah laut mendekati kemusyrikan dan oleh karenanya mereka sepakat untuk tidak memakai ritual tersebut (Wawancara dengan Abdul Rozaq/Pak Donceng, 11 Juni 2014). Perubahan orientasi ini tampaknya bersamaan dengan kehadiran kelompok pengajian Al-Khidmah dan para kiai yang secara rutin datang di Batulawang. Al-Khidmah didirikan oleh K.H. Asrori Al-Ishaqi di Kedinding, Surabaya. Pesantren Al-Fitrah yang diasuhnya sekaligus menjadi pusat gerakan jamaah yang berorientasi pada Tarekat Qadiriyah wa Naqsyabandiyah, salah satu tarekat yang cukup besar di Indonesia. Sejak 2009, tampaknya Karimunjawa menjadi salah satu bidang garap organisasi tersebut.

Meskipun demikian, esensi ritual masih tetap dilaksanakan meskipun mengalami penyederhanaan. Sebelum kapal diluncurkan ke laut, kapal harus terlebih dahulu dimandikan. Hal ini mereka anggap sebagai pelancar rezeki mereka. Ada juga dari mereka yang melengkapi kegiatan memandikan kapal tersebut dengan ritual selametan dan manakiban (pembacaan hagiografi Syaikh Abdul Qodir Al-Jaelani) (Wawancara dengan Tayib, 11 Juni 2014; Wawancara dengan Ahmad Fajar, 11 Juni 2014). Penyederhanaan ritual ini sangat mungkin juga didasari oleh pertimbangan-pertimbangan ekonomi. Ritual yang besar dan rumit membutuhkan banyak biaya dan dianggap sebagai sebuah pemborosan (Wawancara dengan Adnan, 12 Juni 2014).

\section{Peluang Ekonomi Baru: Wisata Bahari Batulawang}

Penetapan zonasi pemanfaatan wisata di perairan Kemujan telah memunculkan beberapa spot wisata penting di Batulawang, seperti Timo' Beach (Pantai Timur), Barek Beach (Pantai Barat) yang memiliki pasir putih dan indah, situs pamujaan, dan goa Jepang di ujung Batulawang. Memang, dampak sektor pariwisata belum terlihat massif di Batulawang, tetapi pertumbuhan pariwisata di Batulawang telah menumbuhkan pelaku-pelaku bisnis wisata baru. 
Abdullah, Kasek, dan Adnan misalnya, adalah beberapa orang yang masuk dalam kategori ini. Setelah belajar dari teman-temannya di Karimunjawa, Abdullah misalnya, mulai merintis homestay di Batulawang pada 2014.

Meskipun dengan fasilitas yang minim, homestay yang ia rintis telah menjadi rujukan para tamu yang ingin menginap di Batulawang. Meskipun mayoritas tamu adalah mahasiswa, Abdullah tampak serius menata homestay-nya dengan penambahan kamar-kamar dan pemenuhan air yang melimpah. Senada dengan Abdullah adalah Kasek dan Adnan yang masingmasing telah membangun homestay bergaya rumah panggung adat Bugis (Wawancara dengan Adnan, 12 Juni 2014). Dilihat dari sektor pariwisata, Batulawang tampak mulai berbenah dari ketertinggalannya selama ini dari Karimunjawa. Hal ini dapat dilihat dari kemudahan penyewaan kapal untuk wisata yang sudah dilengkapi dengan jaket keselamatan (pelampung), dan peralatan snorkling.

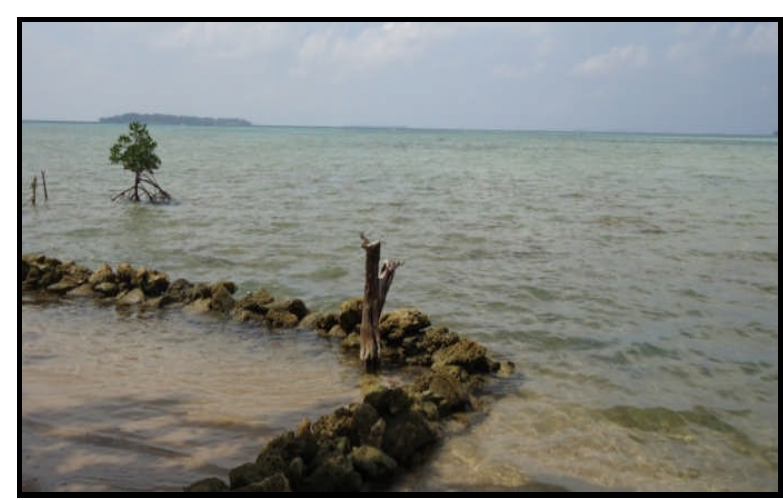

Gambar 8. Pantai Timur Batulawang dalam tahap penataan. Susunan batu karang digunakan oleh penduduk lokal untuk menahan debit pasir (Sumber: Dokumentasi Peneliti)

Meskipun geliat pariwisata mulai tampak di Batulawang, beberapa kendala masih membelit para pelaku usaha wisata di daerah tersebut. Berkaitan dengan pengembangan wisata di Batulawang, terdapat dua faktor penghambat yang utama, baik eksternal maupun internal. Faktor eksternal berkaitan dengan kebijakan pengembangan pariwisata yang dirasa masih berpusat di Desa Karimunjawa. Mereka menyebut Karimunjawa (baca: Pusat Kecamatan
Karimunjawa) sebagai 'anak emas' wisata di Kepulauan Karimunjawa. Persoalan infrastruktur jalan dan akses komunikasi juga menjadi hal yang sangat menghambat. Sebetulnya, jarak Karimunjawa ke Batulawang hanya $18 \mathrm{~km}$. Akan tetapi, karena infrastruktur jalan yang buruk di banyak tempat, membuat perjalanan ke Batulawang menyita banyak waktu. Meskipun demikian, wilayah ini telah memiliki ketersediaan listrik 24 jam dan jaringan Telkomsel sejak 2016. Keduanya, sangat esensial bagi pengembangan dunia pariwisata.

Meskipun demikian beberapa tokoh masyarakat Batulawang mengakui, meskipun setahap demi setahap, jika disiapkan dengan baik wisata di Batulawang dapat dikembangkan lebih besar. Akan tetapi, secara internal, tampaknya keinginan ini mendapat hambatan dari beberapa tokoh masyarakat Batulawang. Menurut mereka Batulawang belum siap menjadi destinasi wisata (Wawancara dengan Yuslam Said/Mantan Kades Kemujan, 11 Juni 2014). Akan tetapi, para pelaku bisnis wisata baru di Batulawang berpendapat, jika menunggu siap kapan Kemujan dapat bersaing dengan desa yang lain. Abdullah, Adnan, dan Kasek mengakui jika saatnya tiba, mereka tidak mau hanya menjadi penonton saja (Wawancara dengan Abdullah, 12 Juni 2014; Wawancara dengan Adnan, 13 Juni 2014). Fenomena yang perlu mendapat perhatian adalah adanya beberapa lahan di Batulawang yang berpindah kepemilikan ke tangan pihak lain. Fenomena ini massif terjadi pada 2010 sampai dengan awal 2014.

\section{SIMPULAN}

Berdasarkan uraian di atas, tampak bahwa nelayan Bugis Batulawang telah mengembangkan berbagai strategi adaptasi sebagai respon terhadap perubahan lingkungan yang muncul dari penetapan Kepulauan Karimunjawa sebagai Taman Nasional. Melalui berbagai strategi adaptasi ekonomi tersebut, nelayan Bugis Batulawang telah memperlihatkan diri sebagai masyarakat yang memiliki fleksibilitas. Dengan cara itu, mereka mampu mempertahankan 
kelangsungan hidup sebagai etnik maritim dalam lingkungan yang telah berubah.

\section{CATATAN}

${ }^{1}$ Artikel ini adalah bagian dari Laporan Penelitian berjudul "Strategi Adaptasi Ekonomi Komunitas Bugis di Dusun Batulawang, Kelurahan Kemujan, Kecamatan Karimunjawa”. Laporan Hibah Kompetensi Fakultas Ilmu Budaya, Universitas Diponegoro, 2014, dengan mengalami perubahan-perubahan.

\section{REFERENSI}

Ahimsa-Putra. Shri (2003). Ekonomi Moral, Rasional dan Politik dalam Industri Kecil di Jawa. Yogyakarta: Kepel Press.

Amaruli, Rabith Jihan (2013), “Uang Naik dalam Sistem Perkawinan Suku Bugis di Karimunjawa: Sebuah Penelitian Awal”. Laporan Penelitian Individu Fakultas Ilmu Budaya Universitas Diponegoro.

Balai Taman Nasional Karimunjawa (2009). Survei Sosial Ekonomi Kepulauan Karimunjawa. Semarang: Balai Taman Nasional Karimunjawa-Dirjen Perlindungan Hutan dan Konservasi AlamDepartemen Kehutanan.

Balai Taman Nasional Karimunjawa (2012). Zonasi Taman Nasional Karimunjawa Tahun 2012. Semarang: Balai Taman Nasional Karimunjawa.

Bennet, John W. (1969). Northern Plainsmen: Adaptive Strategy and Agararian Life. Chicago: Aldine Transaction Publisher.

Gottschalk, Louis (2008). Mengerti Sejarah (diindonesiakan oleh Nugroho Notosusanto). Jakarta: UI-Press.

Hamid, Abu (2005). Passompe Pengembaraan Orang Bugis. Makassar: Pustaka Refleksi.

Jurusan Sejarah dan Program Magister Ilmu Sejarah Universitas Diponegoro (2012). "Laporan Kegiatan Penelitian Sosial dan Pengabdian kepada Masyarakat di Desa Kemujan Kecamatan Karimunjawa Kabupaten Jepara”. Kerjasama Jurusan Sejarah dan Program Magister Ilmu Sejarah Universitas Diponegoro dan
Markas Besar TNI Angkatan Laut Republik Indonesia.

Kesuma, Andi Ida (2004). Migrasi dan Orang Bugis. Yogyakarta: Penerbit Ombak.

Kuntowijoyo (2003). Metodologi Sejarah. Yogyakarta: Tiara Wacana.

Kusnadi (2000). Nelayan; Strategi Adaptasi dan Jaringan Sosial. Yogyakarta: LkiS.

Miles, Matthew B. dan A. Michael Huberman, (1992). Analisis Data Kualitatif: Buku Sumber tentang Metode-metode Baru. Jakarta: UI-Press.

Mubyarto, Loekman Soetrisno, dan Michael Dove (ed.). (1984). Nelayan dan Kemiskinan: Studi Ekonomi Antropologi di Dua Desa Pantai. Jakarta: Rajawali.

Ortiz, Sutti (2005). "Decision and Choices: The Rastionality of Aconomic Actors", dalam James G. Carrier, editor. A Handbook of Economic Anthropology. Cheltanham UK dan Northampton USA: Edward Elgar Publishing, hlm. 59-77.

Pelras, Christian (2006). Manusia Bugis, terjemahan Abdul Rahman Abu. Jakarta: Nalar.

Renier, G.J. (1997). Metode dan Manfaat Ilmu Sejarah, terjemahan Muin Umar. Yogyakarta: Pustaka Pelajar.

Semedi, Pujo (2003). Close to the Stone, Far from the Throne: The Story of Javanese Fishing Community, 1820's-1990's. Yogyakarta: Benang Merah.

Suliyati, Titiek (2013). "Etnis Bugis di Karimunjawa: Harmoni dalam Pelestarian Budaya dan Tradisi”. Laporan Penelitian Individu Fakultas Ilmu Budaya Universitas Diponegoro.

Susilowati, Endang (2012). "Etnik Maritim dan Permasalahannya” dalam Asep Karsidi et.al. NKRI dari Masa ke Masa. Bogor: Sains Press.

Susilowati, Endang dan Rabith Jihan Amaruli (2013). "Migrasi, Etnisitas, dan Integrasi Sosial dalam Masyarakat Karimunjawa”. Laporan Penelitian Hibah Kompetensi Fakultas Ilmu Budaya Universitas Diponegoro Semarang. 
Widodo, Sutejo K. (2005). Ikan Layang Terbang Menjulang: Perkembangan Pelabuhan Pekalongan menjadi Pelabuhan Perikanan, 1900-1990. Semarang: Undip Press.

\section{INFORMAN}

Abdullah, wiraswastawan

Abdul Rozak/ Pak Donceng, Kepala Dusun

Adnan, Pengelola Homestay dan Patai Timo'

Ahmad Fajar, nelayan

Andi, buruh

Jamaludin, nelayan

Sulaiman, nelayan

Tayib, nelayan

Watabe', nelayan

Yuslam Said, mantan Kepala Desa 